\title{
A MICRO-METHOD FOR SERUM CALCIUM AND SERUM MAGNESIUM
}

\author{
BY \\ R. H. WILKINSON \\ From the Department of Chemical Pathology, The Hospital for Sick Children, \\ Great Ormond Street, London
}

(RECEIVED FOR PUBlication AUgUST 2, 1956)

A simple, rapid, accurate method for determining calcium and magnesium separately in $0.1 \mathrm{ml}$. volumes of serum (or heparinized plasma) was required for the routine chemical pathology service of a children's hospital (Wilkinson, 1955-6). The apparatus used had to be generally available, the minimum of pipetting and transfer was desirable for the sake of accuracy, and the method had to be specific. Sobel and Hanok (1951) determined the sum of serum calcium and magnesium by direct titration with the disodium salt of ethylene-diamine tetra-acetic acid (E.D.T.A.) using eriochrome black $\mathrm{T}$ as the metal indicator. This indicator has a relatively sharp visual end-point. If serum calcium could be determined in a similar way then magnesium could be found by difference. Murexide (ammonium purpurate) in alkaline solution is a specific indicator for calcium in serum. The colour change of the calcium murexide complex to the free dye is gradual and the visual end-point of a titration with E.D.T.A. is not sharp (Davis and Smith, 1953). The colour change of the alkaline dye solution with calcium has been used as a colorimetric method (Williams and Moser, 1953 ; Gorsuch and Posner, 1955), but the fading is rapid. Diggins (1955) has reported a method of stabilizing the colour. An alternative procedure is to titrate serum calcium with E.D.T.A. using murexide as an indicator and to determine the end-point photometrically. Schwarzenbach (1955) has reviewed the whole subject of complexometric titrations. He showed the curves of colour change of indicator versus the volume of titrant added, for murexide and eriochrome black $T$ in the presence of calcium and magnesium at different $p \mathrm{H}$ levels. The theory of spectrophotometric titrations with complexones has been discussed by Fortuin, Karsten, and Kies (1954) and Ringbom and Vanninen (1954). Methods which use these principles for the photometric titration of calcium have been described by Holtz and Seekles (1952), Kibrick, Ross, and
Rogers (1952), Lehmann (1953), Fales (1953), Chalmers (1954), Poulie (1954), Karsten, Kies, van Engelen, and de Hoog (1955), Eldjarn, Nygaard, and Sveinsson (1955), and Horner (1955). An investigation of this type of analysis is described below and a simple method has been evolved for analysing $0.1 \mathrm{ml}$. quantities of serum for calcium and calcium plus magnesium.

\section{Apparatus}

A single-cell photoelectric absorptiometer (Evans Electroselenium Ltd.) was fitted with a 36-watt bulb to read optical densities of 0.8 to 1.2 (meter readings 0 to 60). Ilford spectrum filters 606 (peak transmission $575 \mathrm{~m} \mu$ ) and 607 (peak transmission $600 \mathrm{~m} \mu$ ) and a $1 \mathrm{~cm}$. cuvette (volume $7 \mathrm{ml}$.) were used. A simple light shutter was used to protect the cell and galvanometer. An " agla" micrometer syringe burette (Burroughs Wellcome Ltd.) fitted with a bent glass delivery tube was used to deliver the E.D.T.A. into the cuvette below the liquid surface (Fig. 4). The burette capacity was $0.5 \mathrm{ml}$.; it delivered with an accuracy of 0.00005 $\mathrm{ml}$. and was graduated in $0.0002 \mathrm{ml}$. A Hilger "uvispek" spectrophotometer was used to measure the absorption curves only.

\section{Reagents}

All reagents were prepared and stored in plast:c containers wherever possible.

Distilled Water.-Water from an ion exchange column was used.

Murexide Indicator for Calcium (6 mg. per $100 \mathrm{ml}$.) -Approximately $6 \mathrm{mg}$. of murexide (ammonium purpurate acid) was measured in a calibrated glass tube $(1 \mathrm{~mm}$. diameter, $5 \mathrm{~mm}$. deep) and dissolved in $100 \mathrm{ml}$. of distilled water. The strength of the solution was $\stackrel{\infty}{+}$ adjusted so that when $0.4 \mathrm{ml}$. of $\mathrm{N}$ alkali was added 0 to $5 \mathrm{ml}$. of the dye solution the optical density (O.D.) was 1.1 to 1.2 (50 on the extinction scale of the $\mathbb{\Phi}$ absorptiometer using full light) at $1 \mathrm{~cm}$. depth, $606 \frac{O}{\mathrm{D}}$ filter. The solution was made up each day. The $\varrho$ polythene container was washed out carefully after use, as traces of old indicator depressed the colour $O$ change with calcium. 
E.D.T.A. Solution (4.804 g. per litre). -The disodium salt of ethylene-diamine tetra-acetic acid $\left(\mathrm{C}_{10} \mathrm{H}_{14}\right.$ $\mathrm{O}_{8} \mathrm{~N}_{2} \mathrm{Na}_{2} 2 \mathrm{H}_{2} \mathrm{O}$ ) (mol, wt. 372.3) (Hopkin and Williams Ltd., $98 \%$ minimum purity) was dried at $110^{\circ} \mathrm{C}$. for four hours and placed in a desiccator overnight, and then $4.804 \mathrm{~g}$. of the salt was dissolved and made up to 1 litre in distilled water.

N. Alkali--Aqueous solution of tetramethyl ammonium hydroxide (approximately $2.5 \mathrm{~N}$ ), $25 \%$ $\mathrm{w} / \mathrm{w}$, was diluted with distilled water and standardized at $\mathbf{N}=1.0$.

Calcium Standard (Neutral, $10 \mathrm{mg}$. per $100 \mathrm{ml}$.). Pure dry calcium carbonate A.R., 0.250 g., was dissolved in $6 \mathrm{ml}$. of $\mathbf{N}$ hydrochloric acid and heated on a boiling water-bath until the excess of hydrochloric acid was driven off. When cool the calcium chloride was transferred with washings to a 1-litre flask and diluted to the mark with distilled water.

Methanol Absolute.-Methanol absolute was redistilled in an all-glass apparatus.

Eriochrome Black T Stock Solution.-Eight hundred milligrams of the dye (G. T. Gurr Ltd.) were dissolved in $200 \mathrm{ml}$. of absolute redistilled methanol and $8.0 \mathrm{ml}$. of concentrated ammonia solution A.R. (S.G. $=0.88$ ) was added. This solution was stable for six months.

Ethanolamine (2-Hydroxyethylamine B.P. $1^{\circ}{ }^{\circ}$ C.). -It was necessary to redistill some batches in the same way as the methanol to remove blank.

Buffer Indicator Solution for Magnesium.-To $100 \mathrm{ml}$. of distilled water were added $1.0 \mathrm{ml}$. of ethanolamine and $1.7 \mathrm{ml}$. of the eriochrome black $\mathrm{T}$ stock solution. The buffer indicator (approximately $0.17 \mathrm{M}$. ethanolamine) with the addition of $0.1 \mathrm{ml}$. of aqueous standard or serum had a $p \mathrm{H}$ of 10.4 , and using a $1 \mathrm{~cm}$. light path and 607 filter had an O.D. of 1.2 (or 50 on the extinction scale of the absorptiometer using full light). The volume of stock dye solution necessary to give an O.D. of 1.2 varied slightly from batch to batch. The buffer indicator solution was prepared freshly each day.

Stock Magnesium Standard (100 mg. per $100 \mathrm{ml}$.).Dry $\mathrm{MgSO}_{4} 7 \mathrm{H}_{2} \mathrm{O}$ (A.R.), $10.131 \mathrm{~g}$., was dissolved in distilled water and the volume made up to 1 litre.

Magnesium Standard (2 mg. per $100 \mathrm{ml}$.). - Two millilitres of the stock standard were diluted to $100 \mathrm{ml}$. with distilled water.

\section{Method}

Unless it is stated otherwise in the text, the titrations were carried out as described in the appendix.

\section{The Titration of Calcium in Aqueous Solution}

An aqueous solution of murexide $(5 \mathrm{mg}$. per $100 \mathrm{ml}$.) lost $20 \%$ of its O.D. (using the 606 filter, $1 \mathrm{~cm}$. light path) when it was brought to $p \mathrm{H} 12.6$ after 48 hours. A fresh solution of murexide when held at $p \mathrm{H} 12.6$ lost $20 \%$ of its O.D. in 30 minutes. At higher $p \mathrm{H}$ levels the loss of colour was greater. The free indicator faded slightly faster than the calcium complex. This fading did not affect the titration method described.

The absorption spectrum of a murexide and calcium murexide solution changed as the $p \mathrm{H}$ was raised. The conditions of the test were similar to those used in the suggested method. While the maximum absorption of the free dye moved from 520 at $p \mathrm{H} 5.5$ to $550 \mathrm{~m} \mu$ at $p \mathrm{H} \mathrm{12.6,} \mathrm{the} \mathrm{maximum}$ O.D. of the calcium complex at these $p \mathrm{H}$ levels only moved from 520 to $530 \mathrm{~m} \mu$. The maximum O.D. difference between the free dye and the complex at $p \mathrm{H} 12.6$ occurred at $570 \mathrm{~m} \mu$ and was practically as great between 565 and $585 \mathrm{~m} \mu$ (Fig. 1). The filter 606 used in the standard method had a maximum absorption of $575 \mathrm{~m} \mu$ and gave the largest O.D. difference between the free murexide and calcium complex.

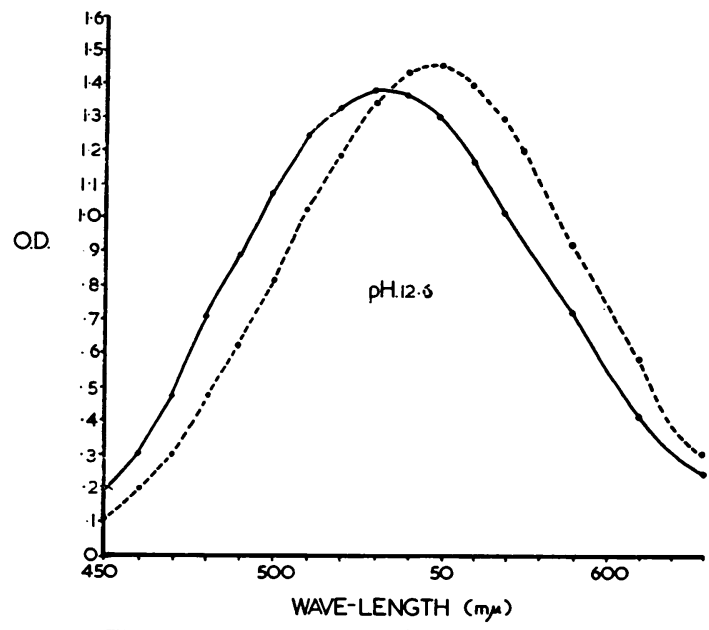

FIG. 1.- The absorption spectrum of free murexide (-.-.-.) and calcium complex (-O- - at $p \mathrm{H} 12.6$.

The indicator concentration changed the form of the titration curve. Above a concentration of $3 \mathrm{mg}$. per $100 \mathrm{ml}$. the titration plot of O.D. versus volume of titrant changed from a curve to a straight line. The range of O.D. between the calcium complex and the free form increased with increasing strength of dye. The O.D. of the $6 \mathrm{mg}$. per $100 \mathrm{ml}$. indicator using a 606 filter was the highest O.D. that could be measured with convenience on the absorptiometer.

The concentration of E.D.T.A. had no effect on the titration curve. Above $p \mathrm{H} 11.5$ calcium in the presence of magnesium titrated in aqueous solution with the correct amount (100 divisions) of E.D.T.A. solution. Below $p \mathrm{H} 11.5$ magnesium 
interfered considerably and gave falsely high readings. This agreed with the observations of Kibrick et al. (1952).

The standard titration of 100 divisions of E.D.T.A. solution allowed $10 \mu \mathrm{g}$. of calcium to be determined accurately. Less than $5 \mu \mathrm{g}$. yielded too few points for plotting even with additions of 10 divisions of titrant. Therefore $10 \mu \mathrm{g}$. of calcium was added to the unknown solution before the titration. Fading of the murexide colour became a nuisance if more than $15 \mu \mathrm{g}$. of calcium were titrated with additions of 20 divisions of titrant. Therefore a single large addition of titrant was added first to leave about $10 \mu \mathrm{g}$. of calcium for titration in the usual manner. These titrations from 1 to $40 \mathrm{mg}$. per $100 \mathrm{ml}$. gave an accuracy of $\pm 0.1 \mathrm{mg}$. per $100 \mathrm{ml}$. in aqueous solution with or without magnesium being present

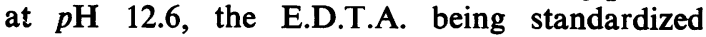
against $0.1 \mathrm{ml}$. of $10 \mathrm{mg}$. per $100 \mathrm{ml}$. calcium standard.

\section{Titration of Calcium in Serum or Plasma (Heparinized)}

Whereas aqueous solutions of calcium when titrated at or above $p \mathbf{H} 11.5$ gave satisfactory recoveries, it can be seen from the curves in Fig. 2 that the observed calcium level in serum fell as the alkali was increased. The minimum level was observed with the addition of $0.4 \mathrm{ml}$. or more of $\mathrm{N}$. alkali ( $p \mathrm{H}$ of greater than 12.6). Greater additions of alkali gave no lower readings but depressed the colour of the indicator and increased its rate of fading as was shown before. The procedure was carried out on numerous children's sera and on horse sera and rabbit sera ; $0.4 \mathrm{ml}$. of $\mathrm{N}$. alkali was always sufficient to depress the observed calcium level to the minimum. This amount of alkali was used in the standard method for children's and horse sera.

The addition of sodium chloride up to final concentration in the cuvette of $90 \mathrm{mM}$ per litre (三 4.5 molar in the $0.1 \mathrm{ml}$. serum) and the addition of three times the concentration of the anions and cations found in plasma had no effect on the volume of titrant used but depressed the colour of the indicator. The same effect occurred in the aqueous calcium titration. Heparinized plasma gave the same results as serum and lipaemia had no effect on the end-point. Magnesium had no effect on the calcium titration, as can be seen in the section on recoveries.

\section{Titration of Magnesium}

The sum of calcium and magnesium present in $0.1 \mathrm{ml}$. of serum or heparinized plasma was deter-
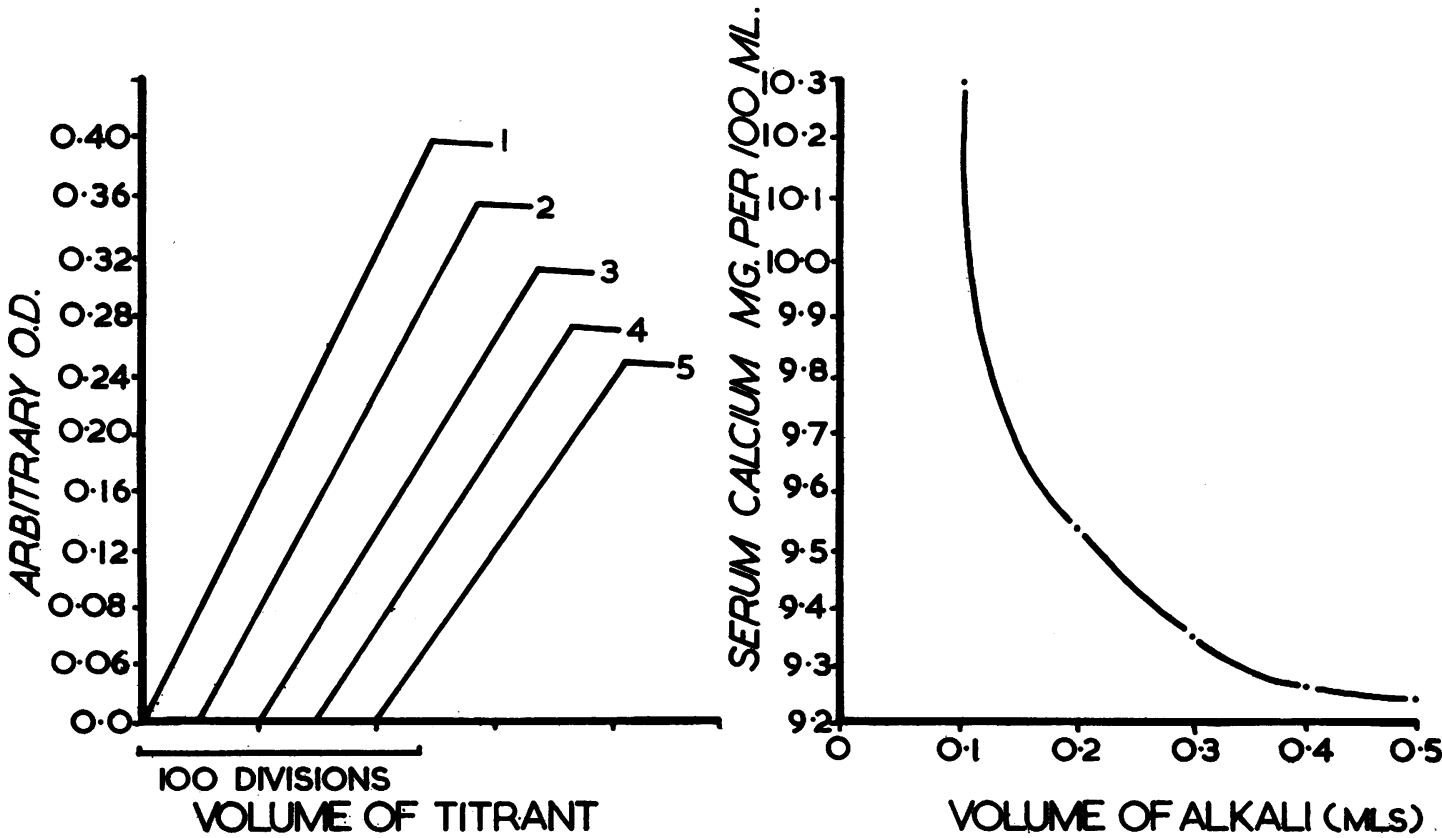

Fig. 2. - The effect of $\mathrm{pH}$ on the serum calcium titration; $0.1 \mathrm{ml}$. of serum was titrated in the standard way except that the following amounts of N. alkali were used: (1) $0.1 \mathrm{ml} ., p H 11.9$, (2) $0.2 \mathrm{ml}$., $p \mathrm{H} 12.3$, (3) $0.3 \mathrm{ml}$., pH 12.5, (4) $0.4 \mathrm{ml}$, ,pH 12.65 , and (5) $0.5 \mathrm{ml} ., p H 12.7$. 
mined using eriochrome black $T$ as the metal indicator. The same apparatus was used and the plot of O.D. versus volume of titrant was similarly arranged to produce two straight lines crossing each other at the end-point. The difference between the eriochrome and the murexide titrations gave an accurate determination of the magnesium content of the serum. A detailed description of the method is given in the appendix.

Eriochrome blue black B was found to be no better than eriochrome black $\mathrm{T}$ as an indicator. The alkaline methanol stock solution of the indicator was stable. Sufficient of this solution was added to an aqueous ethanolamine buffer to produce an O.D. of approximately 1.2 (607 filter, peak $600 \mathrm{~m} \mu$ ). This gave a sufficiently long straight line near the end-point of the titration plot. The indicator showed the same change in O.D. from metal complex to free dye with 2.5 times less metal than murexide and the final straight part of the curve of O.D. versus volume of titrant corresponded to about $4 \mu \mathrm{g}$. of calcium. To obtain sufficient points the extinction readings covering the last five additions of 10 divisions of titrant were plotted. In order to titrate accurately less than $4 \mu \mathrm{g}$. of calcium or its equivalent as magnesium, calcium was added to the unknown solution for titration. For convenience, quantities of metal greater than $4 \mu \mathrm{g}$. of calcium or its equivalent had a sufficient volume of E.D.T.A. added to them to bring them approximately to this figure. In practice E.D.T.A. was added until the O.D. could be read on the absorptiometer scale using full light.

Ethanolamine buffer (approximately $0.17 \mathrm{M}$ ) produced the correct $p \mathrm{H}$ with serum and with inorganic solutions, as Sobel and Hanok (1951) described. Blank amounts of calcium and magnesium were found in both the ethanolamine and methanol used for the buffer indicator solutions and were removed by distillation. Tests with Ilford spectrum filters showed that number 607 (peak $600 \mathrm{~m} \mu$ ) gave the greatest O.D. difference between the metal complex and free indicator. Alterations in the strength of the E.D.T.A. titrant had no effect on the accuracy of the titration and it was used in the same concentration as the cal. cium method. Thus 100 divisions were equivalent to $10 \mu \mathrm{g}$. of calcium or to $6 \mu \mathrm{g}$. of magnesium.

When either calcium or magnesium was used to standardize the E.D.T.A. solution, the eriochrome titration in aqueous solutions had an accuracy of $\pm 0.1 \mathrm{mg}$. per $100 \mathrm{ml}$. in the ranges 0.2 to $10 \mathrm{mg}$. per $100 \mathrm{ml}$. of magnesium and 1 to $40 \mathrm{mg}$. per 100 ml. of calcium.

\section{Recoveries of Calcium and Magnesium in Serum}

Doubling and halving the amounts of a serum and the double titration on serum showed good agreement between the amounts of calcium and magnesium found (Table I). Additions of calcium and magnesium to the serum in the cuvette were recovered quantitatively by the murexide and

TABLE I

RECOVERY OF CALCIUM AND MAGNESIUM IN SERUM BY THE MUREXIDE AND ERIOCHROME TITRATIONS

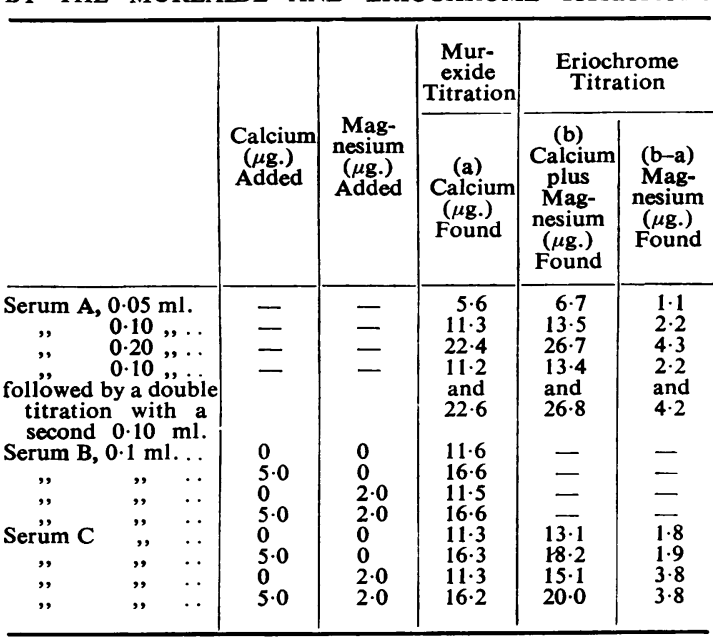

eriochrome titrations. The addition of magnesium did not affect the murexide titration within the limits of experimental error of the method $( \pm 0.1 \mathrm{mg}$. per $100 \mathrm{ml}$.). These recoveries were repeated several times using sera from children, adults, and horses with similar results.

\section{Comparison of the Murexide with Oxalate Precipitation Method}

Numerous analyses of children's sera, adult sera, and horse sera showed that the murexide method gave calcium figures which averaged $0.7 \mathrm{mg}$. per $100 \mathrm{ml}$. lower than those obtained with the oxalate precipitation method. The oxalate method of Clark and Collip (1925) was used, but the precipitate was washed by the method of Halverson and Bergeim (1917). This method is referred to hereafter as the oxalate method. A representative example of nine children's sera analysed by both methods is shown in Table II. An attempt was made to compare recoveries by the two methods in a more fundamental way. Calcium and magnesium were removed from a serum, then added in known amounts and recoveries made. 
TABLE II

COMPARISON OF CALCIUM CONTENT OF 9 CHILDREN'S SERA MEASURED BY MUREXIDE AND OXALATE METHODS

\begin{tabular}{|c|c|c|c|}
\hline & $\begin{array}{l}\text { (a) } \\
\text { Murexide } \\
\text { Method } \\
\text { (mg. per } \\
100 \mathrm{ml} .)\end{array}$ & $\begin{array}{c}\text { (b) } \\
\text { Oxalate } \\
\text { Precipitation } \\
\text { Method } \\
\text { (mg. per } 100 \mathrm{ml} \text {.) }\end{array}$ & $\begin{array}{l}(\mathrm{b}-\mathrm{a}) \\
(\mathrm{mg} \cdot \mathrm{per} \\
100 \mathrm{ml} .)\end{array}$ \\
\hline $\begin{array}{cc}\text { Serum } & 1 \\
,, & 2 \\
, & 3 \\
, & 4 \\
., & 5 \\
, & 6 \\
, & 7 \\
, & 8 \\
, & 9\end{array}$ & $\begin{array}{r}6 \cdot 7 \\
8 \cdot 4 \\
9.4 \\
9 \cdot 6 \\
9 \cdot 7 \\
10 \cdot 4 \\
11.6 \\
12.4 \\
14.4\end{array}$ & $\begin{array}{r}7 \cdot 4 \\
9.0 \\
10 \cdot 4 \\
10 \cdot 3 \\
10 \cdot 2 \\
11 \cdot 3 \\
12 \cdot 2 \\
13 \cdot 2 \\
15 \cdot 2\end{array}$ & $\begin{array}{l}+0.7 \\
+0.6 \\
+1.0 \\
+0.7 \\
+0.5 \\
+0.9 \\
+0.6 \\
+0.8 \\
+0.8\end{array}$ \\
\hline
\end{tabular}

Average of excess of oxalate precipitation methods $=\quad 0 \cdot 7$

Horse serum was passed through a column containing "zeokarb" 225 cation exchange resin in the sodium form (Messrs. Permutit Ltd.). The column measured $25 \mathrm{~cm}$. long and $2.5 \mathrm{~cm}$. in diameter and was half-filled with the resin $(75 \mathrm{ml}$. when fully swollen). The resin was brought to the $\mathrm{H}$. form by passing $500 \mathrm{ml}$. of $2 \mathrm{~N}$. hydrochloric acid A.R. through the column. It was brought to the $\mathrm{Na}$ form with $500 \mathrm{ml}$. of $10 \%$ sodium carbonate A.R. Then $200 \mathrm{ml}$. of a saturated aqueous solution of E.D.T.A. brought to $p \mathrm{H} 13$ with $60 \%$ sodium hydroxide was passed through the column to remove any traces of calcium and magnesium. The column was washed with 1 litre of glass-distilled water. Then $250 \mathrm{ml}$. of horse serum was passed through the column at a rate not greater than $45 \mathrm{ml}$. per hour. The last two
$100 \mathrm{ml}$. portions of the effiuent serum were collected. Varying amounts of $500 \mathrm{mg}$. per $100 \mathrm{ml}$. standard calcium solution and $100 \mathrm{mg}$. per $100 \mathrm{ml}$. standard magnesium solution were delivered from an "agla" syringe burette into $5 \mathrm{ml}$. volumetric flasks and made up to the mark with the serum. The sera were analysed by the murexide and eriochrome methods for calcium and magnesium and by the oxalate method for calcium.

The recoveries are shown in Table 111 . The $\overrightarrow{0}$ serum alone was shown to contain no calcium or $\overrightarrow{\vec{\omega}}$ magnesium by the murexide, eriochrome, and oxalate titrations within the experimental error of the methods. The oxalate titration of the serum equalled the blank titration of the reagents which included the amount of permanganate required to show the end-point. Thus protein by itself did not affect the permanganate titration. The calcium series i ( 2 to $22 \mathrm{mg}$. per $100 \mathrm{ml}$. calcium with 2 mg. per $100 \mathrm{ml}$. magnesium) showed that the murexide titration gave satisfactory recoveries except at the 18 and $22 \mathrm{mg}$. levels where the recovery was $0.3 \mathrm{mg}$. too low. The eriochrome titration showed a similar depression of magnesium at these high calcium levels. The magnesium series i (1 to $4 \mathrm{mg}$. per $100 \mathrm{ml}$. of magnesium in the presence of $10 \mathrm{mg}$. per $100 \mathrm{ml}$. of calcium) showed good recoveries of calcium and magnesium. Raised levels of magnesium did not affect the murexide titration for calcium. The calcium series ii (6 to $18 \mathrm{mg}$. per $100 \mathrm{ml}$. calcium

TABLE III

RECOVERY OF CALCIUM BY OXALATE AND MUREXIDE METHODS AND CALCIUM AND MAGNESIUM BY ERIOCHROME METHOD OF CALCIUM AND MAGNESIUM ADDED TO RESIN-TREATED SERUM

\begin{tabular}{|c|c|c|c|c|c|c|}
\hline & \multirow{2}{*}{$\begin{array}{l}\text { Calcium } \\
\text { Added to Serum } \\
(\mathrm{mg} . \text { per } 100 \mathrm{ml} .)\end{array}$} & \multirow{2}{*}{$\begin{array}{c}\text { Magnesium } \\
\text { Added to Serum } \\
\text { (mg. per } 100 \mathrm{ml} .)\end{array}$} & \multirow{2}{*}{$\begin{array}{c}\begin{array}{c}\text { Oxalate } \\
\text { Precipitation }\end{array} \\
\begin{array}{c}\text { Calcium Found } \\
(\mathrm{mg} . \text { per } 100 \mathrm{ml} .)\end{array}\end{array}$} & \multirow{2}{*}{ 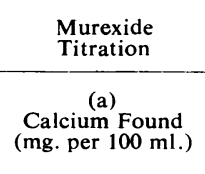 } & \multicolumn{2}{|c|}{$\begin{array}{c}\text { Eriochrome } \\
\text { Titration }\end{array}$} \\
\hline & & & & & $\begin{array}{l}\text { (b) } \\
\text { Calcium plus } \\
\text { Magnesium Found } \\
\text { (mg. per } 100 \mathrm{ml} .)\end{array}$ & $\begin{array}{l}(b-a) \\
\text { Magnesium Found } \\
\text { (mg. per } 100 \mathrm{ml} .)\end{array}$ \\
\hline $\begin{array}{l}\text { Resin-treated } \\
\text { serum alone }\end{array}$ & 0 & 0 & $0 \cdot 0$ & $0 \cdot 1$ & $0 \cdot 1$ & $0 \cdot 0$ \\
\hline Calcium series $\mathrm{i}$ & $\begin{array}{r}2 \cdot 0 \\
6 \cdot 0 \\
10 \cdot 0 \\
14 \cdot 0 \\
18 \cdot 0 \\
22 \cdot 0\end{array}$ & $\begin{array}{l}2 \cdot 0 \\
2 \cdot 0 \\
2 \cdot 0 \\
2 \cdot 0 \\
2 \cdot 0 \\
2 \cdot 0\end{array}$ & $\begin{array}{l}5 \cdot 9, \quad 5 \cdot 5 \\
10 \cdot 0,10 \cdot 0 \\
14 \cdot 3,14 \cdot 2 \\
17 \cdot 0,17 \cdot 4 \\
22 \cdot 4,22 \cdot 7\end{array}$ & $\begin{array}{l}2.0(5) \\
6.0(5) \\
10 \cdot 0 \\
13.9(5) \\
17.7 \\
21 \cdot 7\end{array}$ & $\begin{array}{r}4.0(2) \\
8.0(9) \\
11.9(7) \\
16.0(0) \\
19.4(5) \\
23.4(0)\end{array}$ & $\begin{array}{l}1.9(7) \\
2.0(4) \\
1.9(7) \\
2.0(5) \\
1.7(5) \\
1.7(0)\end{array}$ \\
\hline $\begin{array}{l}\text { Magnesium } \\
\text { series } i\end{array}$ & $\begin{array}{l}10 \cdot 0 \\
10 \cdot 0 \\
10 \cdot 0 \\
10 \cdot 0\end{array}$ & $\begin{array}{l}1 \cdot 0 \\
2 \cdot 0 \\
3 \cdot 0 \\
4 \cdot 0\end{array}$ & $\begin{array}{r}9 \cdot 8, \quad 9 \cdot 8 \\
10 \cdot 0,10 \cdot 0 \\
9 \cdot 7, \quad 9 \cdot 8 \\
9 \cdot 9, \quad 9 \cdot 8\end{array}$ & $\begin{array}{l}10 \cdot 0(5) \\
10 \cdot 0 \\
10 \cdot 1 \\
10 \cdot 1\end{array}$ & $\begin{array}{l}11.0(2) \\
11.9(7) \\
13.0(7) \\
13.9(8)\end{array}$ & $\begin{array}{l}0.9(7) \\
1.9(7) \\
2.9(7) \\
3.8(8)\end{array}$ \\
\hline Calcium series & $\begin{array}{r}6 \cdot 0 \\
10 \cdot 0 \\
14 \cdot 0 \\
18 \cdot 0\end{array}$ & $\begin{array}{l}0 \\
0 \\
0 \\
0\end{array}$ & $\begin{array}{r}5 \cdot 8, \quad 5 \cdot 7 \\
10 \cdot 1,10 \cdot 1 \\
14 \cdot 5,14 \cdot 0 \\
18 \cdot 7,18 \cdot 6\end{array}$ & $\begin{array}{l}6 \cdot 0(5) \\
10 \cdot 0 \\
14 \cdot 0 \\
17 \cdot 8\end{array}$ & $\begin{array}{l}6 \cdot 1 \\
10 \cdot 0 \\
14 \cdot 0 \\
17 \cdot 7(5)\end{array}$ & $\begin{array}{l}0 \cdot 0(5) \\
0.0 \\
0 \cdot 0 \\
0 \cdot 0(5)\end{array}$ \\
\hline \multirow[t]{2}{*}{$\begin{array}{l}\text { Magnesium } \\
\text { series ii }\end{array}$} & 0 & $2 \cdot 0$ & $0 \cdot 1,0 \cdot 1$ & $0.1^{*}$ & $2 \cdot 1$ & 2.0 \\
\hline & & & $\begin{array}{l}\text { Duplicates as } \\
\text { shown }\end{array}$ & \multicolumn{3}{|c|}{ All figures duplicated to $\pm 0.1 \mathrm{mg}$. per $100 \mathrm{ml}$. } \\
\hline
\end{tabular}


with no added magnesium) allowed the recoveries of calcium by murexide and eriochrome to be compared directly. Here again at the $18 \mathrm{mg}$. level the recovery was depressed in both methods of titration. The magnesium series ii showed again that magnesium did not affect the murexide titration. The oxalate titration figures for all these series, however, did not show the expected excess of determined calcium. It was felt that the resin column treatment presumably had altered the serum or the conditions of the estimation in some unknown way and that the only way to compare the murexide and oxalate methods was in actual use. No further duplicate analyses were performed, since the murexide method required only $0.1 \mathrm{ml}$. of plasma from capillary blood whereas the oxalate method required $2 \mathrm{ml}$. of serum obtained by venipuncture. By this time the murexide method was in routine use and it was felt unjustifiable to return to obtaining blood by venipuncture from children for a large series of calcium determinations.

From January, 1955, until April, 1956, 710 consecutive routine requests for serum calcium from children coming to the hospital were received and analysed by the murexide method. Seven hundred and twelve consecutive analyses by the oxalate precipitation method were also taken from the three years before January, 1955. The two groups were analysed by plotting the frequencies of the estimations in $0.1 \mathrm{mg}$. intervals and the means and standard deviations were calculated.

The two groups showed a difference of $0.85 \mathrm{mg}$. per $100 \mathrm{ml}$. of calcium between the oxalate and murexide methods (Fig. 3). The mean of the oxalate method was 10.48 and of the murexide method was 9.63. The two groups included all the sera, pathological and normal, which were sent

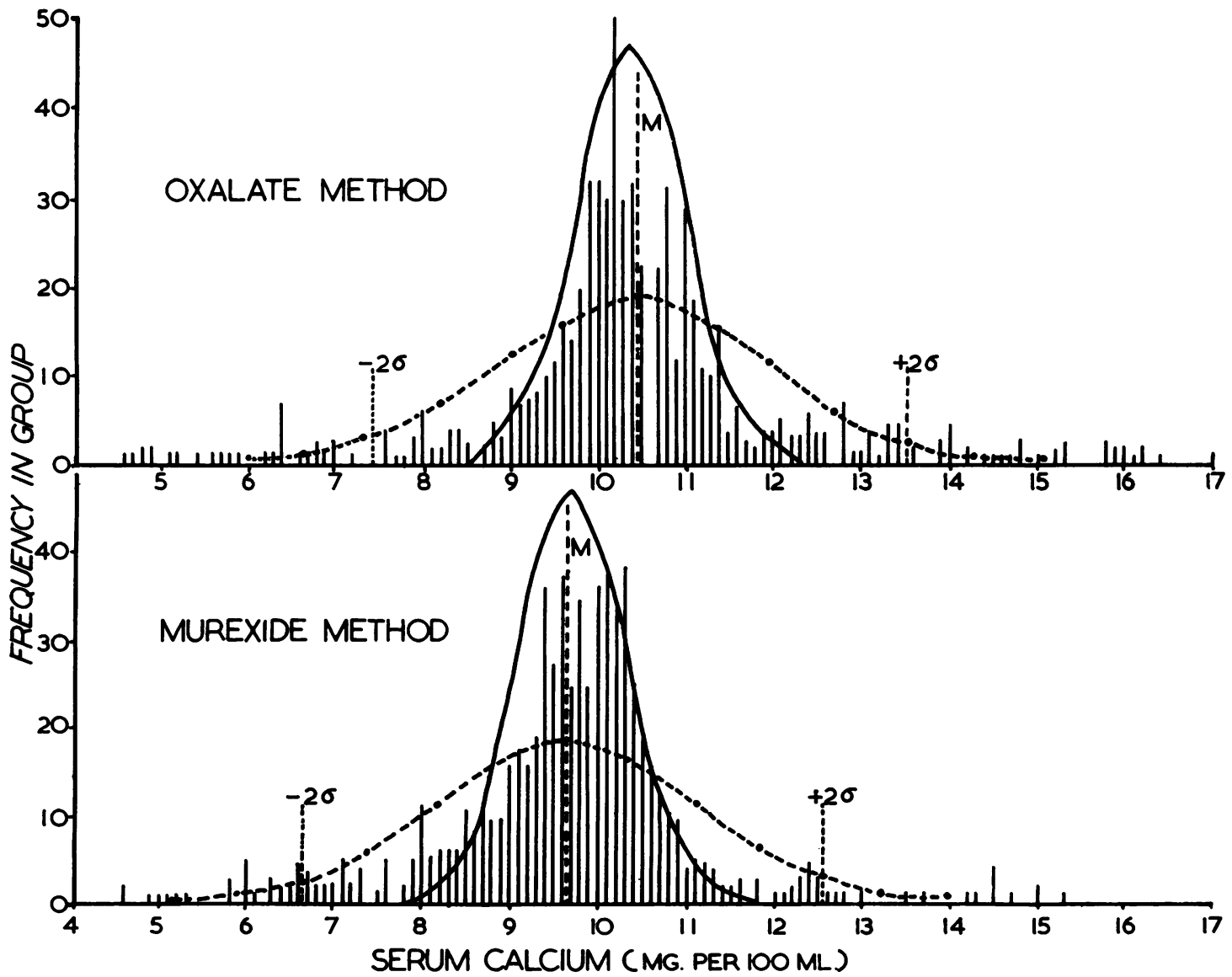

Fig. 3.-Frequency distribution of 712 serum calcium estimations by the oxalate method and 710 estimations by the murexide method in $0.1 \mathrm{mg}$. per $100 \mathrm{ml}$. groups, - - actual normal curve for each series with $M$ (mean) and $\pm 2 S$ (standard deviations) marked. theoretical normal curve $(S$ assumed $=0.6$ ) fitted to central group of each series. 
for serum calcium determination. The oxalate group showed an excess of 35 estimations below and 39 above two standard deviations from the mean. The murexide group showed an excess of 32 estimations below and only 17 above two standard deviations from the mean. The mean of the latter was corrected approximately by adding 15 more estimations in the $13.0 \mathrm{mg}$. interval. This corrected mean was 9.72 and differed from the oxalate mean by $0.76 \mathrm{mg}$. per $100 \mathrm{ml}$. If these two large groups with sinilar standard deviations (oxalate $S=1.53(4)$ and murexide $S=1.47(6)$ ) be assumed to be fairly homogeneous, the estimate of the excess of calcium estimated by the oxalate method, compared with that estimated by the murexide method, is $0.8 \mathrm{mg}$. per $100 \mathrm{ml}$.

An attempt was made to find out the normal range of serum calcium using the central group of the murexide figures. Assuming a normal distribution, a theoretical normal curve with a standard deviation of 0.6 was fitted to the central group (Fig. 3, murexide, full line). It is suggested that, until a large series of normal children have been investigated, this curve approximates closely enough to the normal to be of use in determining the normal range. Thus a clinically normal calcium result would be between 8.9 and $10.5 \mathrm{mg}$. per $100 \mathrm{ml}$. (10\% and $90 \%$ levels). The $1 \%$ and $99 \%$ levels would be 8.3 and $11.1 \mathrm{mg}$. per $100 \mathrm{ml}$.

The comparison of serum calcium levels by oxalate precipitation with determinations by other methods is difficult. Each particular variant of the oxalate method gives a different range of normal, e.g., Elkinton and Danowski (1955), Wootton, MacLean-Smith, and King (1950), Smith, Craig, Bird, Boyle, Iseri, Jacobson, and Myers (1950) and Power, Toogood, and Adamson (1956). The oxalate method is subject to losses in washing the precipitate, and to gains due to the amount of ammonium oxalate not washed out of the precipitate and due to the presence of magnesium oxalate. The amount of magnesium oxalate present depends on the $p \mathrm{H}$ of the solution during precipitation and on the length of time the precipitate is allowed to be in contact with the supernatant.

In view of these difficulties, it is not surprising to find that when an oxalate method was compared with a murexide one by Lehmann (1953) and by Eldjarn et al. (1955) the murexide gave lower results, as was found in the present investigation. On the other hand, Kibrick et al. (1952) found that their murexide results agreed with their oxalate results.
Another method of serum calcium determina. tion-emission spectrographic analysis used by Smith et al. (1950) on 86 normal adult sera-gave an average of $8.6 \mathrm{mg}$. per $100 \mathrm{ml}$., which is lower than both the murexide and oxalate methods. Clearly there is some uncertainty about the true levels of calcium in serum. The recoveries obtained by the murexide method described here suggest that they were complete and the method is specific for calcium. The figures were 0.7 to $0.8 \mathrm{mg}$. per $100 \mathrm{ml}$. less than the oxalate method. It is felt that the murexide figures represent the true calcium figure.

\section{Experience with Murexide Method in Routine Use}

Six technicians used the method routinely for 700 estimations in 15 months and two quality control sera were analysed simultaneously. The accuracy was the same as that obtained in an earlier quality control using the oxalate method which was restricted to the use of one skilled person. The comparison showed that the murexide method is quite suited to routine use in a busy laboratory and is capable of the precision required, particularly in paediatrics, for serum calcium determinations on small volumes of serum.

\section{Conclusions}

It was found possible to use a standard photoelectric absorptiometer to measure the change in colour of an alkaline murexide solution as $0.1 \overrightarrow{0}$ $\mathrm{ml}$. of serum or standard was titrated with E.D.T.A. solution delivered from a micrometer burette. The strength of the dye was adjusted so $\frac{0}{3}$ that an adequate change of O.D. occurred using narrow band filters, and the change was a linear function of the volume of titrant added. The endpoint was obtained graphically. The $p \mathrm{H}$ of the $\frac{\text { o }}{2}$ reaction was controlled so that the observed cal- $\rightarrow$ cium level in serum was at a minimum. The magnesium plus calcium titration using eriochrome black $\mathrm{T}$ was arranged to work in a similar manner so that the sum of these ions could be 0 obtained on a second $0.1 \mathrm{ml}$. of serum. The mag- $-\mathrm{C}$ nesium content was then found by difference. The recoveries of added calcium and magnesium (overo the range $0-22 \mathrm{mg}$. per $100 \mathrm{ml}$. and $0-4 \mathrm{mg}$. perत्त $100 \mathrm{ml}$. respectively) from serum which had its? calcium and magnesium removed by an ion exchange resin were satisfactory. The method $\vec{P}$ gave results $0.7-0.8 \mathrm{mg}$. of calcium per $100 \mathrm{ml} \stackrel{\odot}{\odot}$ lower than an oxalate precipitation method and $\overrightarrow{\mathrm{D}}$ a tentative range of normal values for childreno is suggested. 


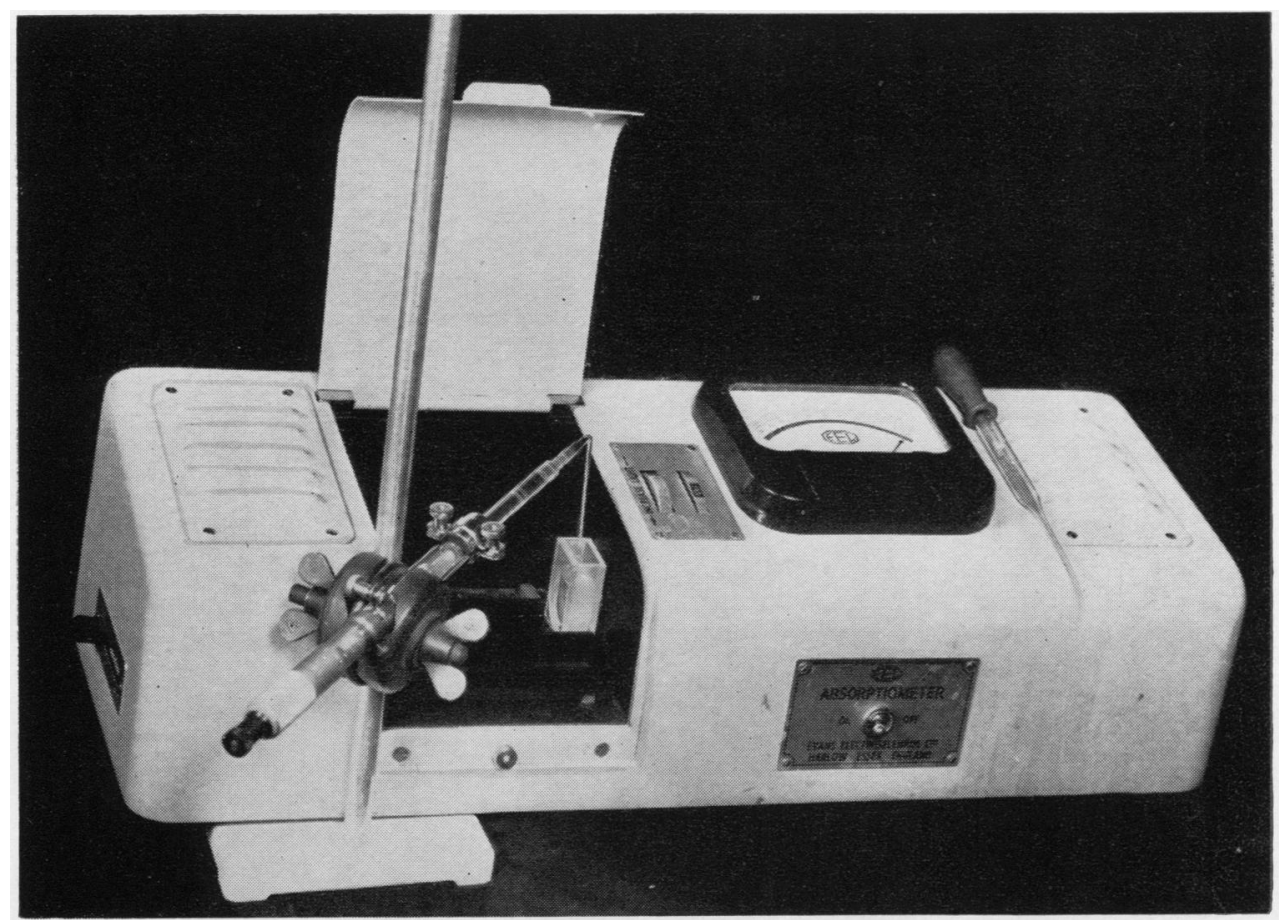

FIG. 4.-The apparatus assembled for the photometric titration showing the E.E.L. absorptiometer, " agla" micrometer syringe burette with tip dipping into the fluid in the cuvette, and Pasteur pipette for mixing.

I would like to offer my sincere thanks to Dr. W. W. Payne for his kind and very helpful advice at numerous points in this investigation, to Dr. C. O. Carter for advice in the statistical analyses, to Mr. D. Martin, Department of Medical Photography, and to Mr. G. Lyth, medical artist, for the illustrations.

\section{A PPEN DIX \\ Method for Calcium and Calcium Plus Magnesium in $0.1 \mathrm{ml}$. Serum}

Apparatus.-Photoelectric absorptiometer measuring O.D. 0.8 to 1.2 with spectrum filter 605 (peak 575-580 $\mu \mathrm{m}$.) and 607 (peak $600 \mu \mathrm{m}$.), i.e., a standard instrument fitted with a more sensitive galvanometer or with a stronger light may be used. Connexions to the bulb should be soldered for stability and a simple light shutter is necessary. A $1 \mathrm{~cm}$. cuvette of about $6 \mathrm{ml}$. capacity is reserved for the estimation. A micrometer syringe burette delivering to $\pm 0.00005 \mathrm{ml}$. accuracy equipped with a bent glass delivery tip is required. The apparatus is arranged as in Fig. 4.

Reagents.-Water, murexide indicator, E.D.T.A., $\mathrm{N}$. alkali, calcium standard $(10 \mathrm{mg}$. per $100 \mathrm{ml}$.) buffer indicator for magnesium, magnesium standard $(2 \mathrm{mg}$. per $100 \mathrm{ml}$.) as described in the text.

Technique for Calcium.-All pipettes, the cuvette, and the polythene bottle for the indicator solution are rinsed with glass-distilled water (but not dried) before and after use. The burette is washed several times with E.D.T.A. solution and filled. No lubricant is used on the plunger. Standard calcium solution, $0.1 \mathrm{ml}$., is delivered from a calibrated $0.1 \mathrm{ml}$. constriction pipette into $5.0 \mathrm{ml}$. of murexide indicator solution in the $1 \mathrm{~cm}$. cuvette and then $0.4 \mathrm{ml}$. of $\mathrm{N}$. alkali is added. The solutions are mixed by aspiration into, and expulsion from, a large Pasteur pipette fitted with a $2 \mathrm{ml}$. rubber teat. The cuvette is placed in position in the absorptiometer ; the burette is adjusted and placed with its glass delivery tip dipping below the fluid level in the cuvette. The shutter is opened using the maximum amount of light available and the O.D. read using the 606 filter. The shutter is closed, 20 divisions of E.D.T.A. solution $(0.004 \mathrm{ml}$.) are added to the cuvette, the cuvette contents are mixed with the Pasteur pipette, and the O.D. read again. These actions are repeated until the O.D. reaches a peak and has then fallen for two further additions of E.D.T.A. The readings on the instrument scale are plotted against divisions of E.D.T.A. added as in the curve for murexide in Fig. 5. The point of intersection of the two straight lines denotes the end-point. One hundred divisions of E.D.T.A. are equivalent to $10 \mu \mathrm{g}$. of calcium $(0.1 \mathrm{ml}$. of 10 mg. \% standard). The cuvette and Pasteur pipette are rinsed with distilled water. The procedure is repeated with $0.1 \mathrm{ml}$. of serum delivered from a $0.1 \mathrm{ml}$. washout pipette. 


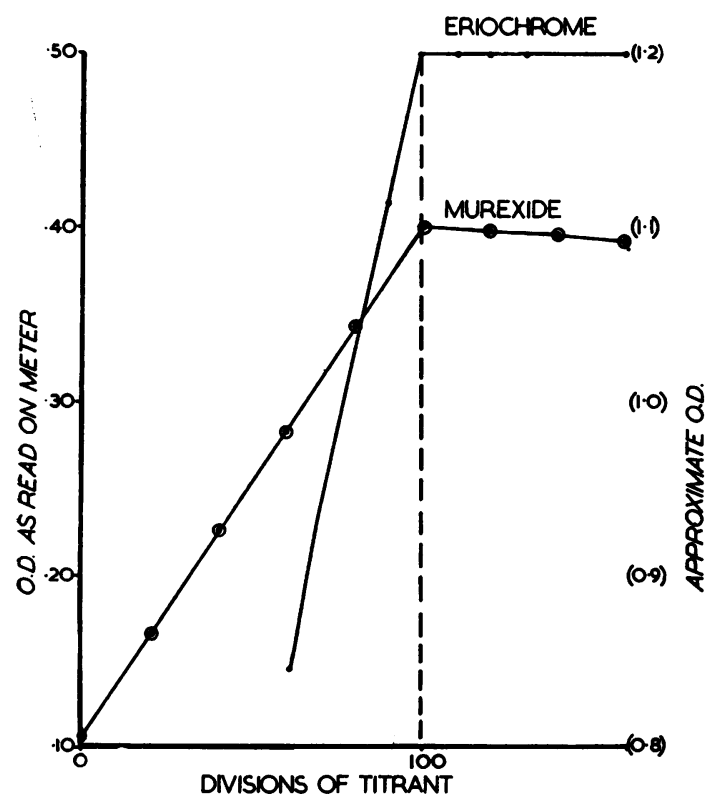

FIG. 5.-Method of graphic determination of the end-point of the titrations using murexide (calcium) and eriochrome (calcium plus magnesium), $0.1 \mathrm{ml}$. of calcium standard titrated in each case.

Calculation.-This is a below :

Titration of serum (in divisions) Titration of standard (100) $\times 10=\mathrm{mg}$. Ca per $100 \mathrm{ml}$.

Each titration and plotting takes five minutes. Assembling the apparatus, etc., takes 15 minutes.

\section{Technique for Magnesium Plus Calcium}

The apparatus is prepared as for the calcium method. Standard calcium solution, $0.1 \mathrm{ml}$., is delivered into $5.0 \mathrm{ml}$. of eriochrome black $T$ buffer solution in the cuvette. The cuvette is placed in the absorptiometer, the burette tip arranged to dip into the solution, and 60 divisions of E.D.T.A. are added $(0.012 \mathrm{ml}$.). The solutions are mixed with the Pasteur pipette and the O.D. read with the maximum light available (filter 607). The readings are taken after further additions with mixing of 10 division portions $(0.002 \mathrm{ml}$.) of E.D.T.A. solution until the O.D. is stationary for two readings. It is necessary to observe the reading for several seconds when the endpoint is approached using eriochrome black $T$ as the reaction slows appreciably. The readings of O.D. against divisions of titrant added, are plotted, as in Fig. 5, line for eriochrome, and the end-point read as the intersection of the two straight lines. The procedure is repeated with $0.1 \mathrm{ml}$. of serum after rinsing out the cuvette and Pasteur pipette. As a working rule the number of divisions of
E.D.T.A. required for the serum calcium titration. minus 10 should be added initially in the serum titra $\vec{F}$ tion, then the O.D. of the solution after mixing is measured. The O.D.s after 10 division additions of E.D.T.A. are plotted as in the titration of the $\operatorname{stan} \underline{\underline{\underline{s}}}$. dard. Four or five points are necessary for the rising branch of the titration curve after the initial addition of the E.D.T.A.

Calculation.-This is as follows : $\frac{\text { Titration (divisions) eriochrome - titration (murexide) }}{\text { Titration of magnesium standard }} \times 2=\underset{\text { magnesiur. }}{100 \mathrm{mgr}}$

Initially, the method is standardized also by using? $0.1 \mathrm{ml}$. of magnesium standard $(2 \mathrm{mg}$. per $100 \mathrm{ml}$.) If the standard calcium reads 100 divisions, then themagnesium standard should read 33 (by chemica equivalence). No initial addition of E.D.T.A. is needed with the magnesium standard titration to bring the readings on the straight line working parto of the curve.

Technique for Detecting Blanks in Reagents

To $5 \mathrm{ml}$. murexide solution is added $0.1 \mathrm{ml}$. standard and $0.4 \mathrm{ml}$. N. alkali. The titration is carriedo out as usual. After two decreasing O.D.s have been recorded, a second $0.1 \mathrm{ml}$. standard is added to the cuvette and the contents mixed. The O.D. is reado and the titration continued to the second end-poins (Fig. 6). Titration $2-$ titration $1=$ true reading of standard, and titration 1 -true reading = blank readingo

Very low calcium levels in serum may be measured

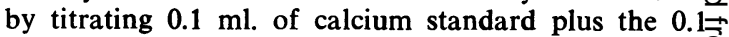
ml. serum. Very high calcium levels may be titrated? by adding E.D.T.A. initially before the first O.D? reading. The blanks and high and low levels of magnesium and calcium in the eriochrome black. titration are detected in a similar manner by doubles titrations and additions of standard or E.D.T.A.

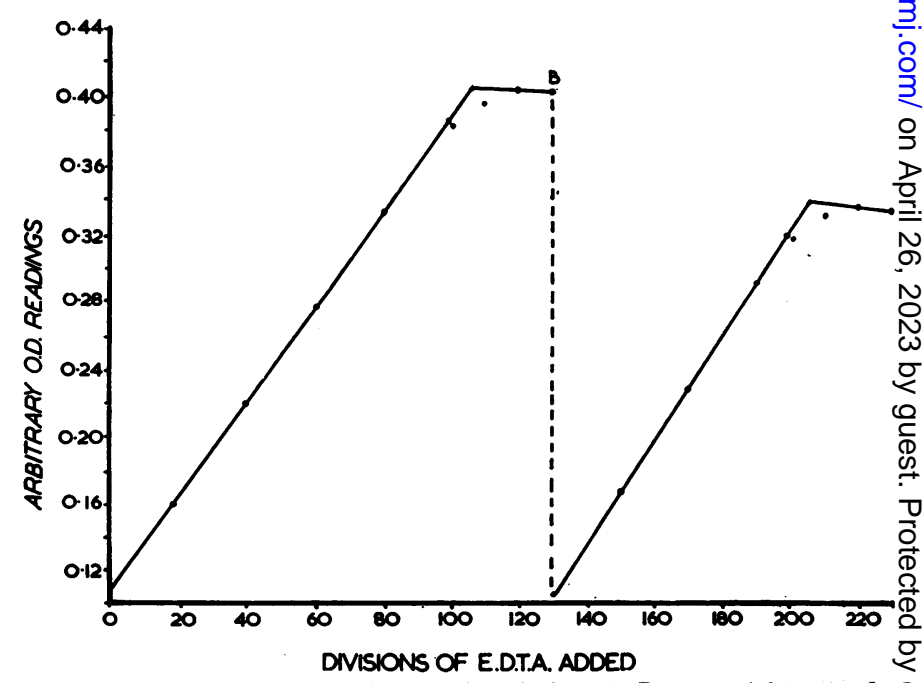

Fig. 6. -The double titration for detecting blanks. At $B$ a second $0.1 \mathrm{ml}$. of calcium standard was added and the titration continued. 


\section{Calcium and Magnesium Estimations in Urine}

The morpholine precipitation of phosphates proposed by Horner (1955) has been used with the proposed method using $2 \mathrm{ml}$. amounts of urine, $0.5 \mathrm{ml}$. of the supernatant fluid ( $\equiv 0.2 \mathrm{ml}$.) was titrated for calcium and gave very reproducible results.

\section{REFERENCES}

Chalmers, R. A. (1954). Analyst, 79, 519.

Clark, E. P., and Collip, J. B. (1925). J. biol. Chem., 63, 461.

Davis, L. R., and Smith, M. J. H. (1953). Journal of Clinical Pathology, 6, 198.

Diggins, F. W. (1955). Analyst, 80, 401.

Eldjarn, L., Nygaard, O., and Sveinsson, S. L. (1955). Scand. J. clin. Lab. Invest., 7, 92.

Elkinton, J. R., and Danowski, T. S. (1955). The Body Fluids. Williams and Wilkins, Baltimore.

Fales, F. W. (1953). J. biol. Chem., 204, 577.

Fortuin, J. M. H., Karsten, P., and Kies, H. L. (1954). Anal. chim. Acta, 10, 356 .
Gorsuch, T. T., and Posner, A. M. (1955). Nature (Lond.), 176, 268. Halverson, J. O., and Bergeim, O. (1917). J. biol. Chem., 32, 159. Holtz, A. H., and Seekles, L. (1952). Nature (Lond.), 169, 870.

Horner, W. H. (1955). J. Lab. clin. Med., 45, 951.

Karsten, P., Kies, H. L., van Engelen, H. T. J., and de Hoog, P. (1955), Anal. chim. Acta, 12, 64.

Kibrick, A. C., Ross, M., and Rogers, H. E. (1952). Proc. Soc. exp. Biol. (N.Y.), 81, 353.

Lehmann, J. (1953). Scand. J. clin. Lab. Invest., 5, 203.

Poulie, N. J. (1954). Chem. Weekbl., 50, 698.

Power, M. H., Toogood, R., and Adamson, L. (1956). Clin. Chem., 2, 278.

Ringbom, A., and Vanninen, E. (1954). Anal. chim. Acta, 11, 153. Schwarzenbach, G. (1955). Die komplexometrische Titration. Enke, Stuttgart.

Smith, R. G., Craig, P., Bird, E. J., Boyle, A. J., Iseri, L. T., Jacobson, S. D., and Myers, G. B. (1950). Amer. J. clin. Path., 20, 263.

Sobel, A. E., and Hanok, A. (1951). Proc. Soc. exp. Biol. (N.Y.), $77,737$.

Wilkinson, R. H. (1955-G). Gt Ormond Str. J., No. 10, p. 127.

Williams, M. B., and Moser, J. H. (1953). Anal. Chem., 25, 1414.

Wootton, I. D. P., MacLean-Smith, J., and King, E. J. (1950). Quoted in King, E. J. (1951). Micro-Analysis in Medical Biochemistry, 2nd ed., p. 1, Churchill, London. 